\title{
The marine Jurassic of Argentina: a biostratigraphic framework
}

Facultad de Ciencias Naturales y Museo, Universidad Nacional de La Plata, Paseo del Bosque s/n, 1900 La Plata, Argentina.

Email:riccardi@museo.fcnym.unlp.edu.ar

In Argentina the best and most complete marine Jurassic succession is exposed between $32^{\circ}$ and $39^{\circ} \mathrm{S}$, along a N-S belt roughly coincident with the border with Chile. Here all stages, except the Kimmeridgian, are represented by marine facies. Ammonites have provided a biostratigraphic framework to date and correlate lithostratigraphic units and sequences, to reconstruct the history of the marine fill, and allow the development of other palaeontological and geological studies. Recent studies on the systematics and/or biostratigraphy of Andean ammonites have provided the basis for the presentation of a summary of the 45 ammonite zones of the Jurassic of west-central Argentina and to stress its significance in reconstructing the palaeogeographic evolution of that region.

\section{Introduction}

Jurassic rocks in Argentina are present over extensive areas (see Figure 1) and include a large variety of marine and continental facies (see Riccardi et al., 1992). South of $39^{\circ} \mathrm{S}$ marine Jurassic consists of Pliensbachian-Lower Toarcian and uppermost Jurassic strata, represented respectively in central and southern Patagonia. North of $39^{\circ} \mathrm{S}$ marine Jurassic is exposed along a N-S belt roughly coincident with the boundary between Argentina and Chile, up to $31^{\circ} \mathrm{S}$ where it becomes restricted to Chile.

The marine Jurassic generally rests unconformably on Upper Triassic (west-central Argentina) and Upper Jurassic vulcanites (southern Patagonia) or on Upper Paleozoic (west-central Patagonia). Only in the Rio Atuel region (c. $35^{\circ} \mathrm{S}$ ) does the Jurassic rest transitionally on marine Triassic (see Riccardi et al., 2004).

Thus the best and most complete Jurassic succession is exposed in west-central Argentina, i.e. the Aconcagua-Neuquen or, for short, the Neuquen Basin, where all stages, except the Kimmeridgian, are represented by predominantly marine and marginal-marine siliciclastics, with subordinate carbonates and evaporites. The various lithostratigraphical units (Figure 2) have been referred to the Precuyo-Cuyo (Rhaetian-Callovian), Lotena (Middle Callovian-Oxfordian), and Mendoza (Kimmeridgian-Barremian) groups.

Ammonites present in this succession have been extensively studied, especially in the last 35 years and, as a result, a fine biostratigraphic framework has been progressively developed and correlated with the European biochronological standard (see Riccardi et al., 1990a-c, 2000; Hillebrandt et al., 1992). This ammonite zonation has been used, to date and correlate not only lithostratigraphic units, but also stratigraphic discontinuities bounding sequences or genetic depositional units, and finally to reconstruct the history of the marine fill of the Neuquen Basin (see Legarreta and Gulisano, 1989; Legarreta and Uliana, 1996; Lanes, 2005; Vicente 2005,

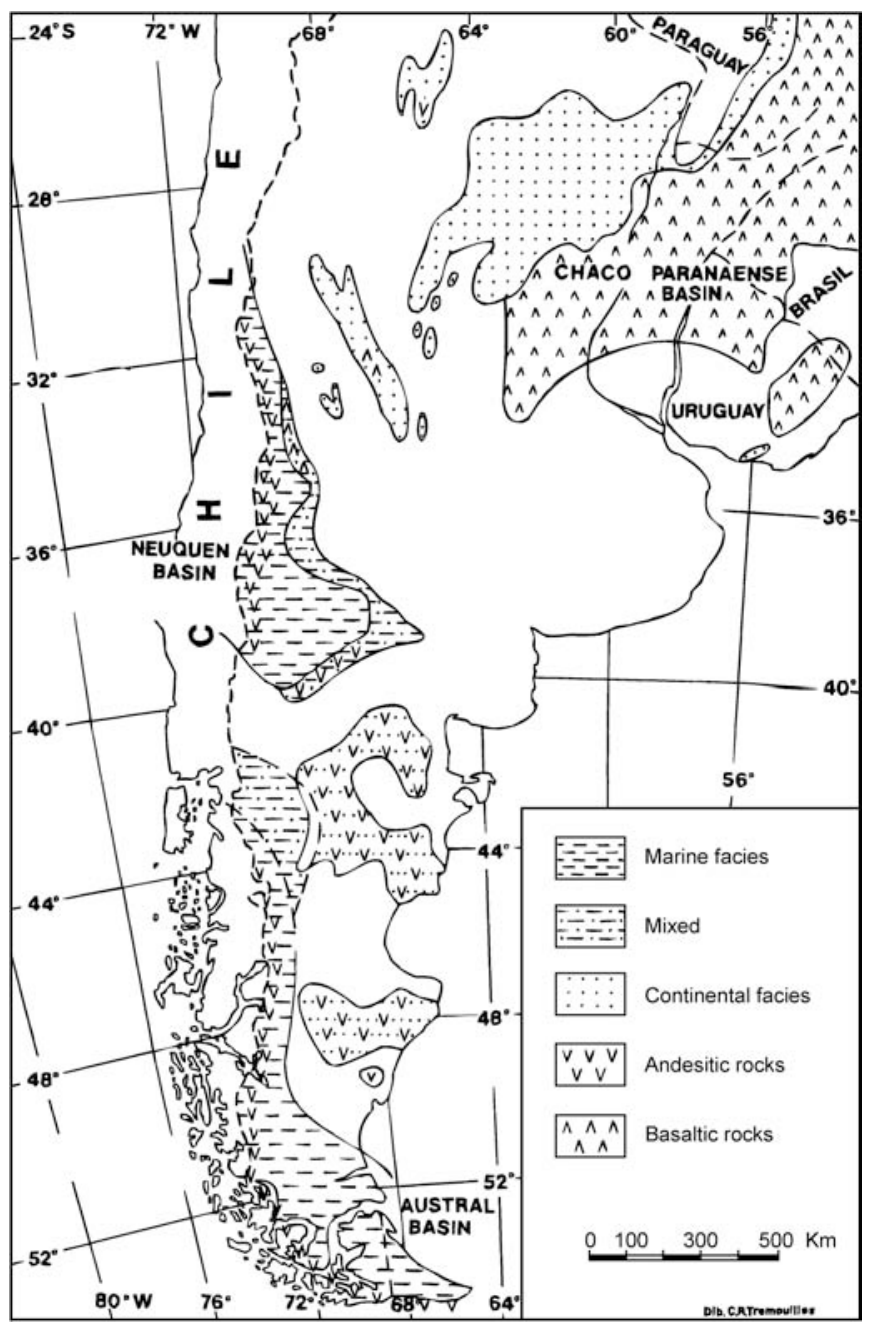

Figure 1 Distribution of Jurassic rocks in Argentina (modified from Stipanicic, 1996).

2006), where the Mesozoic accounts for a large percentage of the Argentine oil and gas production. The same zonation has been found applicable to the marine units exposed in west-central and southern Patagonia, notwithstanding their sparse and poorly preserved faunal record. Additionally ammonite biostratigraphy has provided the basis to biostratigraphic zonations based on other fossil groups, as well as to other paleontological and geological studies, e.g. to document evidence of phyletic gradualism, punctuated equilibrium, and heterochronic processes in Middle Jurassic taxa, to build a Lower Jurassic magnetostratigraphic composite section, to propose an isotope stratigraphy for the Pliensbachian, and to date evidences of a Toarcian global oceanic anoxic event (Riccardi 1985, 2000, 2005; Iglesia Llanos and Riccardi, 2000; Valencio et al., 2005). A number of studies on the systematics and/or biostratigraphy of Andean 


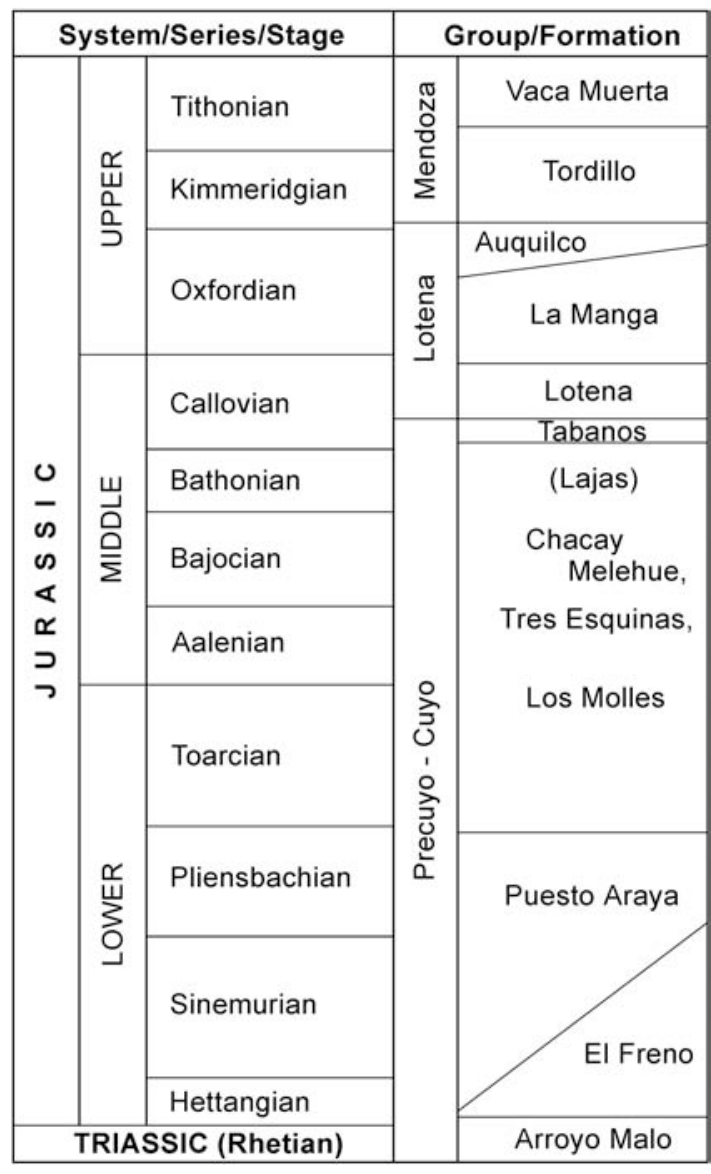

Figure 2 Simplified lithostratigraphic column, west-central Argentina.

ammonites, mostly published in the last 15 years, provided the basis for this summary of the ammonite biostratigraphy of the Jurassic of west-central Argentina and its significance to reconstruct the paleogeographic evolution of that region.

\section{Ammonite biostratigraphy}

Thus far, 45 biozones have been recognized in the Jurassic of westcentral Argentina, 22 in the Lower Jurassic, 14 in the Middle Jurassic and 9 in the Upper Jurassic (Oxfordian and Tithonian). Data analysis included below is based on genera rather than species, as most genera are restricted to one zone. Ranges and means of genera (total $=137$ ) longevity, when analyzed in terms of Andean ammonite zones, give a mean longevity of 1.4.

Using Remane (2000) and Ogg (2004)'s numerical dates, estimation for the average duration of an Argentine Jurassic Zone gives mean longevity for a genus of 0.8 to 1.3 million years. When the Lower, Middle and Upper (restricted to Oxfordian and Tithonian) Jurassic are discriminated, mean genera longevities are, respectively, of $0.6-1.3,1.0-1.5$, and 1.2 million years. Values for the different stages range from 0.5 (Hettangian), 0.7-1.5 (Callovian), and 0.8-1.0 (Tithonian) to 3.5-4.5 (Sinemurian) and 2.0-2.7 (Oxfordian), as expected, considering that the last two include relatively poorly preserved and/or studied faunas.

Accuracy in the correlation of the local ammonite zonation with the European standard zones varies throughout the different stages, as it is closely related to biogeographic changes, which in turn were controlled by changes in sea-level and in migration routes of seaways between the Tethys and eastern Pacific oceans (see Riccardi, 1991).

\section{Lower Jurassic}

Hettangian and Sinemurian fossil assemblages are only present in the Rio Atuel area (c. $35^{\circ} \mathrm{S}$ ). Pliensbachian and Toarcian assemblages are present in west-central Argentina from $30^{\circ}$ to $40^{\circ}$ and have also been recorded from west-central Patagonia.

\section{Hettangian}

Rhaetian and Hettangian ammonites were recorded and figured by Riccardi et al. (see 2004). The Hettangian fauna and biostratigraphy was also described by Hillebrandt (2000).

1. Psiloceras rectocostatum Assemblage Zone. Originally defined from northern Chile (see Hillebrandt, 2000), was extended to the Rio Atuel area, where specimens comparable to the nominal species occur (see Riccardi et al., 2000, 2004). Early Hettangian, Late Plicatulus and Early Johnstoni Subzones of the Planorbis Zone. Ammonites coeval to the Planorbis Subzone have yet to be documented, but they might be represented by c. $80 \mathrm{~m}$, apparently unfossiliferous, between levels with Choristoceras cf. marshi Hauer (Rhaetian) and P. cf. rectocostatum Hill. Loose material, compara-

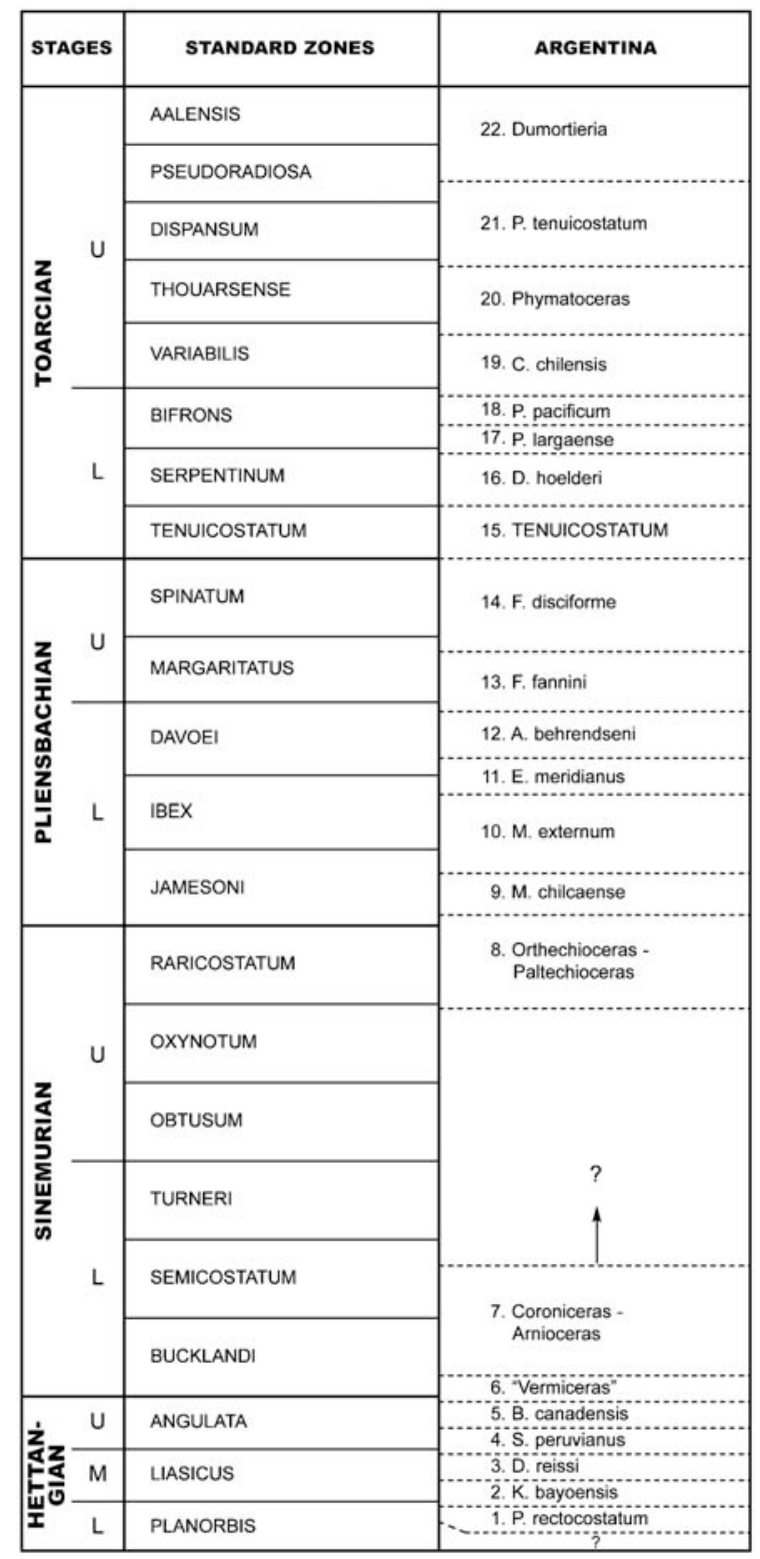

Figure 3 Correlation chart for the Lower Jurassic of west-central Argentina (Duration of stages from Remane, 2000). 
ble with Psiloceras erugatum Buck. and P. pressum Hill., is indicative of the lower to middle part of the Planorbis Zone (see Riccardi et al., 2004).

2. Kammerkarites bayoensis Assemblage Zone. Defined from northern Chile (Hillebrandt, 2000) in Argentina, it appears to be present in the Rio Atuel region (as "Psiloceras Assemblage Zone" in Riccardi et al., 1991), with K. cf. bayoensis Hill. K. cf. chinchillaensis Hill. (MLP 22245), P. cf. crassicostatum (Guex) (MLP 22247) (Figure 4.1), P. sp. (MLP 22248), and "Alsatites cf. liasicus (d`Orb.)". Middle Hettangian, Early Liasicus Zone.

3. Discamphiceras reissi Assemblage Zone. Defined from northern Chile (Hillebrandt, 2000), a few of the included species appear to be present in the Rio Atuel (as lower part of the "Waehneroceras-Schlotheimia Assemblage Zone" in Riccardi et al., 1991), i.e. Kammerkarites cf. diploptychoides Guex (MLP 22249) and Storthoceras cf. frigga (Wahner) (MLP 22251) (Figure 4.2). Middle Hettangian, Late Liasicus Zone.

4. Sunrisites peruvianus Assemblage Zone. Zone defined from northern Chile (Hillebrandt, 2000). Only one species of those included in this zone appears to be present in the Rio Atuel area (as upper part of the "Waehneroceras-Schlotheimia Assemblage Zone" in Riccardi et al., 1991), i.e. Schlotheimia? cf. cachinensis Hill. (MLP 22250, 22252) (Figure 4.3), which occurs together with Paracaloceras cf. coregonense (Sow.). Middle to Late Hettangian, Late Liasicus and Early Angulata Zones.

5. Badouxia canadensis Assemblage Zone. Originally introduced for the Upper Hettangian of the Taseko Lakes, Canada, is represented in the Rio Atuel area (see Riccardi et al., 1991). In northern Chile (Hillebrandt, 2000) it has been divided into two subzones, from below, the Schlotheimia cuevitensis and Paracaloceras varaense Subzones.

In Argentina, the $B$. canadensis assemblage includes, besides the nominal species species (Figures 4.4-5), Paracaloceras cf. rursicostatum Frebold, Angulaticeras $\mathrm{cf}$. marmoreum (Oppel), and Paracaloceras sp. Hettangian (? to Sinemurian), Late Angulata (? to Early Bucklandi) Zones.

6. "Vermiceras Assemblage Zone". Introduced by Riccardi et al. (see 1991) on the basis of "Vermiceras $\mathrm{cf}$. gracile (Spath) and Vermiceras spp.", and considered by Hillebrandt (2000) as equivalent to the upper part of the $P$. varaense Subzone, Canadensis Zone (see above). As indicated by Hillebrandt (2000), material compared with $V$. gracile (see Figures 4.6-7 ) could in fact be referred to Paracaloceras varaense Hill., but this would imply that this species ranges well above the last record of $B$. canadensis, $P$. cf. rursicostatum, and A. cf. marmoreum. Therefore, distinction of two biozones on the basis of this (and other?)Arietitidae cannot be ruled out. Resolution of this issue must await a systematic study, now underway, of the Arietitidae present in the area. (?Hettangian to) Sinemurian, (?Late Angulata to) Early Bucklandi Zone(s).

\section{Sinemurian}

Sinemurian ammonites in Argentina are restricted to the Rio Atuel region, and were figured by Riccardi et al. (1991). Late Sinemurian material was described by Hillebrandt (2002) in a monographic study, where he recognized eleven ammonite horizons, four equivalent to the Obtusum Sandard Zone, two to the Oxynotum S.Z., and five to the Raricostatum S.Z. Thus far only three of the last five have been found in Argentina.

7. Coroniceras-Arnioceras Assemblage Zone. Replacement name for the "Agassiceras Assemblage Zone" of Riccardi et al. (see1991, 2000). With Coron- iceras (C.) cf. alcinoe (Rey.) (Figures 4.8-9), Coroniceras spp. and Pseudaetomoceras? cf. arcuatum Hill. (MLP 22262), and poorly preserved material referable, in part, to Arnioceras spp. Early Sinemurian, Bucklandi and Semicostatum (?to Obtusum) Zones. Pseudaetomoceras arcuatum was used by Hillebrandt (2000) to recognize a faunal horizon at the Hettangian-Sinemurian boundary, overlying the $B$. canadensis Zone and underlying a succession characterized by Arietitidae of the Bucklandi Zone. In the Arroyo Malo section material comparable to this species is present in levels well above the last Badouxia, following levels containing material comparable, in part, with $P$. varaense (see above under "Vermiceras Assemblage Zone").

8. Orthechioceras-Paltechioceras Faunule. Replacement name for the "Epophioceras Faunule" of Riccardi (see Riccardi et al., 1991, 2000). Equivalent to three ammonite horizons defined by Hillebrandt (2002), i.e., from below, Horizon with Orthechioceras

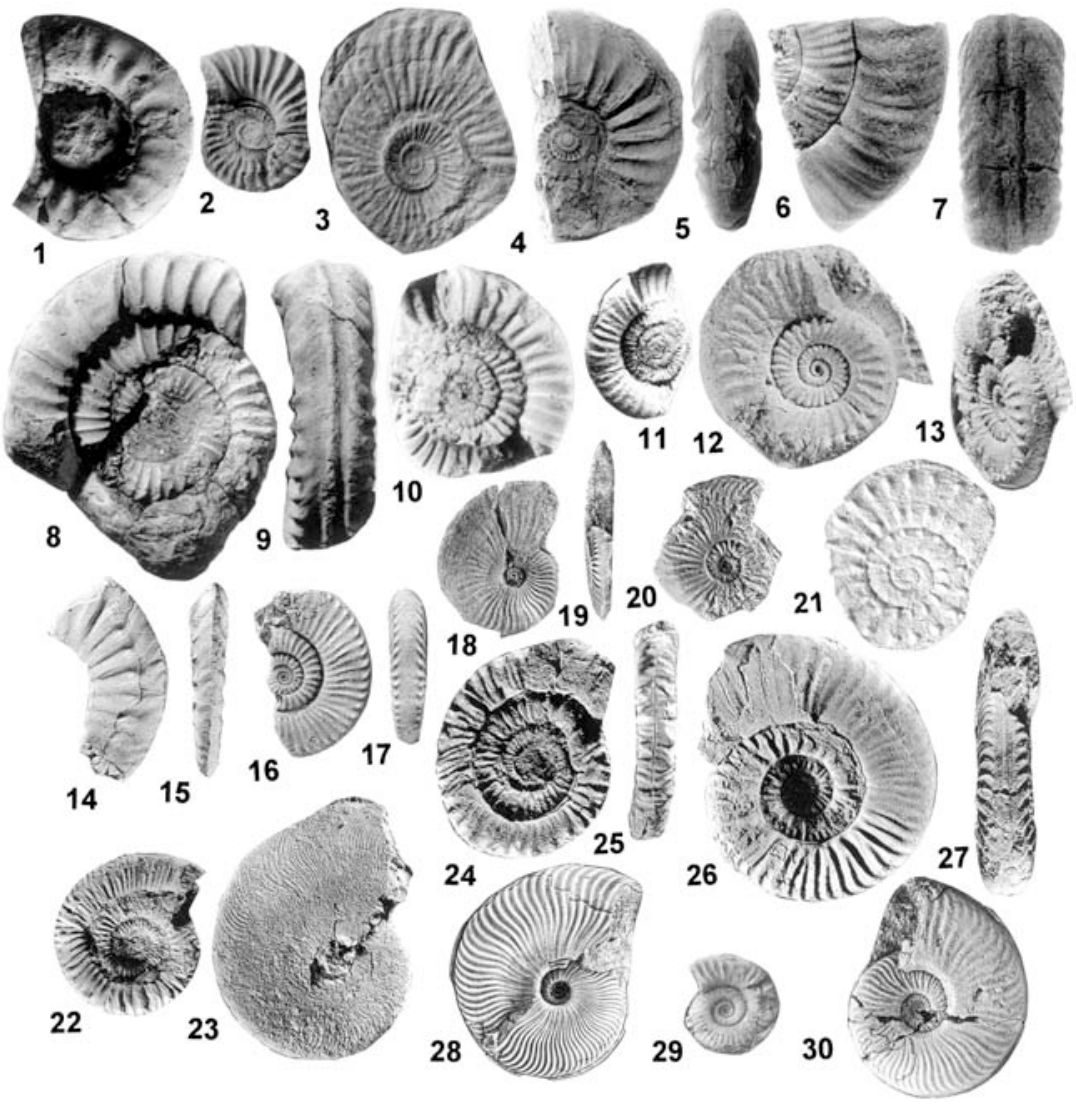

Figure 4 Lower Jurassic ammonites. Hettangian: 1, Psiloceras cf. crassicostatum (Guex) (MLP 22247), 2, Storthoceras cf. frigga (Wahner) (MLP 22251), 3, Schlotehimia? cf. cachinensis Hill. (MLP 22250), 4-5, Badouxia canadensis (Freb.) (MLP 22255); Sinemurian: 6-7, cf. Paracaloceras varaense Hill. (MLP 22259), 8-9, Coroniceras (C.) cf. alcinoe (Rey.) (MLP 22264), 10, Orthechioceras incaguasiense Hill. (TUB 790210/2a/2), 11, Paltechioceras $c f$. tardecrescens (Hauer) (TUB 790210/5/1); Pliensbachian: 12-13, Miltoceras chilcaense Hill. (TUB 790212/2/2), 14-15, Meridiceras $c f$. externum Hill. (TUB 790213/3/4), 16-17, Eoamaltheus parameridianus Hill. (TUB 790209/6/1), 18-19, Austromorphites behrendseni (Jaw.) (SIPUB 65A), 20, Fanninoceras cf. latum McLearn (TUB 841206/3a), 21, Canavaria (Tauromeniceras) sp. (J 21661a); Toarcian: 22, Peronoceras pacificum Hill. (CPBA 17529), 23, Harpoceras subplanatum (Oppel) (CPBA, 17601), 24-25, Collina chilensis Hill. (CPBA 17459), 26-27, Phymatoceras cf. pseudoerbaense (Gabilly) (CPBA 16514), 28, Phlyseogrammoceras? tenuicostatum (Jaw.) (TUB 790222/2), 29, Dumortieria $c f$. pusilla (Jaw.) (TUB 680109/13), 30, Pleydellia $c f$. lotharingica (Branco) (TUB 680109/10). Repositories: CPBA, Universidad de Buenos Aires; J, Naturh. Museum Basel; MLP, Museo de la Plata; SIPUB, Universität Bonn; TUB, Technische Universität Berlin; Figs. 10-21, 28-30, in part modified, from Hillebrandt, 1987, 2002, 2006; 22-27, modified from Alvarez, 1996. All figures $\times 0.28$, except figures $1-3,10-13,21, \times 0.56$. 
incaguasiense and Plesechioceras domeykoense, Horizon with Paltechioceras cf. romanicum, and Horizon with Paltechioceras oosteri and $P$. cf. tardecrescens. This faunule is characterized by $O$. incaguasiense Hillebrandt (MLP 22263) (Figure 4.10), $P$. domeykoense Hill., $P$. cf. romanicum (Uhlig), P. oosteri (Dumortier) and $P$. cf. tardecrescens (Hauer) (Figure 4.11). Late Sinemurian, Raricostatum Zone.

\section{Pliensbachian}

Pliensbachian ammonites are widespread and well known in west-central Argentina (see Riccardi et al., 1991). Pliensbachian material, mostly from the Rio Atuel area, was described and figured by Hillebrandt (2006).

9. Miltoceras chilcaense Assemblage Zone. Introduced by Hillebrandt (2006) for an assemblage typically represented in the Rio Atuel region. Equivalent to the "Miltoceras Faunule" of Riccardi (see Riccardi et al., 1990a, 2000), with M. chilcaense Hill. (Figure 4.12-13), M. reductispinosum Hill., M.? sp. A, Tropidoceras? hamulatum Hill., T. cf./aff. demonense (Gemm.). Early Plienbachian, Early Jamesoni Zone. The regional Pliensbachian stratotype was defined (Westermann and Riccardi, 1989) at the base of this zone, Río Atuel.

10. Meridiceras externum Assemblage Zone. Introduced by Hillebrandt (2006) for an assemblage typically represented in the Rio Atuel region. Equivalent to the lower part of the "Dubariceras Assemblage Zone" of Riccardi et al. (1990a) or "Tropidoceras Zone or Assemblage Zone" of Hillebrandt (1987) and Riccardi et al. (2000). It consists of $M$. cf. externum Hill. (Figures 4.14-15), $M$. celericrescens Hill., M. amolanasense Hill., M. densicostatum Hill., Tropidoceras cf. demonense (Gemm.), T. flandrini cf. flandrini (Dum.), T. f. cf. obtusum (Futt.), T. cf. mediterraneum (Gemm.), $T$. cf./ex gr. zitteli Fuc., T. atuelense Hill., Andicoeloceras sp. A., Dubariceras argentinicum Hill., Liparoceras (L.) cf. cheltiense (Murch.), Phylloceras hebertinum (Rey.), Partschiceras striatocostatum (Meneg.), Juraphyllites libertus australis Hill., J. sp. A. Early Pliensbachian, Late Jamesoni and Early Ibex Zones.

11. Eoamaltheus meridianus Assemblage Zone. Introduced by Hillebrandt $(1987,2006)$ for northern Chile and the Río Atuel region, Argentina. Equivalent to the upper part of the "Dubariceras Assemblage Zone" of Riccardi et al. (1990a, 2000), with E. meridianus Hill., E. parameridianus Hill. (Figures 4.16-17), E. paraovatus Hill., E. multicostatus Hill., E. ovatoides Hill., E. intermissus Hill., E. blancoensis Hill., E. arayaensis Hill.. Calliphylloceras cf. bicicolae (Meneg.), Juraphyllites cf. planispira (Reynes). Early Pliensbachian, Latest Ibex and Early Davoei Zones.

12. Austromorphites behrendseni Assemblage Zone. Introduced by Hillebrandt $(1987,2006)$ for west-central Argentina. Is equivalent to the lower part of the "Fanninoceras Assemblage Zone" of Riccardi (Riccardi et al., 1990a, 2000), with A. behrendseni (Jaworski, incl. A. spinatus Leanza and Blasco, 1990) (Figures 4.18-19), A. volkheimeri (Hill.), A. multiformis (Hill.), A. prorsiflexus (Hill.), A. carinatus (Hill.), A. piutrinensis (Hill.), Zetoceras cf. indicarense (Haas), Fanninoceras sp. A, Liparoceras (Becheiceras) cf. bechei (J. Sow.). Late Early Pliensbachian, Davoei Zone.

13. Fanninoceras fannini Assemblage Zone. Introduced by Hillebrandt (1987, 2006) for northern Chile. In west-central Argentina is equivalent to the middle part of the "Fanninoceras Assemblage Zone" of Riccardi (Riccardi et al., 1990a, 2000), with $F$. fannini McLearn, F. leptodiscus (Behr.), F. cf. latum McLearn (Figure 4.20), F. carlottense McLearn. Late Early and Early Late Pliensbachian, Late Davoei and Early Margaritatus Zones.

14. Fanninoceras disciforme Assemblage Zone. Introduced by Hillebrandt $(1987,2006)$ for northern Chile. Equivalent to the upper part of the "Fanninoceras Assemblage Zone" of Riccardi (see Riccardi et al., 1990a, 2000), in west-central Argentina includes $F$. disciforme Hill., Canavaria (C.) cf. finitima (Fucini), C. (C.) cf. naxensis (Gemm.), C. (C.) cf. pulcherrima (Fuc.), C. (Tauromeniceras) sp. (Figure 4.21), Neolioceratoides sp., Arieticeras sp., Protogram- moceras sp. Late Pliensbachian, Late Margaritatus and Spinatum Zones

\section{Toarcian}

Toarcian ammonites are widespread, but poorly known in westcentral Argentina (see Riccardi et al., 1990a).

15. Tenuicostatum Standard Zone. This European Standard Zone was extended to the Andes (see Hillebrandt, 1987). In Argentina appears to be present with Dactylioceras (Eodactylites) sp., D. (Orthodactylites) sp. Early Toarcian.

16. Dactylioceras hoelderi Assemblage Zone. Introduced for Chile, is present in Argentina (see Hillebrandt, 1987; Riccardi et al., 1990a, 2000; Hillebrandt et al., 1992), with D. hoelderi Hill. and Schm.-Eff., Nodicoeloceras sp., Harpoceratoides cf. alternatus (Simps.), Hildaites cf. murleyi (Moxon). Early Toarcian, Serpentinum Zone.

17-19. Peronoceras largaense, P. pacificum, and Collina chilensis Assemblage Zones. Introduced for Chile, are present in Argentina (see Hillebrandt, 1987; Riccardi et al., 1990a, 2000; Alvarez, 1996) with Peronoceras cf. subarmatum (Y. and B.), P. cf. vortex (Simps.), P. pacificum Hill. and Schm.-Eff. (Figure 4.22), Harpoceras cf. subexaratum Bon., H. subplanatum (Oppel) (Figure 5.23), Frechiella cf. helvetica Renz, Collina chilensis Hill. and Schm.-Eff. (Figures 4.24-25), Maconiceras sp., Polyplectus sp. Late Early and Early Late Toarcian, Bifrons and Early Variabilis Zones.

20. Phymatoceras Assemblage Zone. Equivalent to the $P$. toroense, and $P$. copiapense zones of Hillebrandt (1987). In Argentina (Riccardi et al., 1990a, 2000) with P. copiapense (Moricke), P. ex gr. lilli (Hauer), P. ex gr. erbaense (Hauer), P. cf. pseudoerbaense (Gab.) (Figures 4.26-27). Late Toarcian, latest Variabilis and Thouarsense Zones.

21. Phlyseogrammoceras (?) tenuicostatum Assemblage Zone. Well represented in Argentina (Riccardi et al., 1990a, 2000; Alvarez, 1996), with P. (?) tenuicostatum (Jaw.) (Figure 4.28), "Witchellia" obscurecostata Jaw., Hammatoceras insigne (Schubler), Sphaerocoeloceras cf. brochiiforme Jaw. Late Toarcian, Dispansum Zone.

22. Dumortieria Assemblage Zone. Equivalent to the Pleydellia lotharingica and P. fluitans zones of Hillebrandt (1987). In Argentina (Riccardi, 2000; Riccardi et al., 1990a, 2000) with $D$. pusilla Jaw. (Figure 4.29), Pleydellia spp. (Figure 4.30), Sphaerocoeloceras brochiiforme Jaw., Hammatoceras sp. Late Toarcian, Late Pseudoradiosa and Aalensis Zones.

\section{Middle Jurassic}

Middle Jurassic ammonite assemblages are widespread in westcentral Argentina. Ammonoid biozones were previously summarized by Hillebrandt et al. (1992) and Riccardi et al. (1994), and are updated below.

\section{Aalenian}

23. Bredyia manflasensis Assemblage Zone. Poorly represented in west-central Argentina (see Riccardi et al., 1990b, 2000; Riccardi, 2000). With B. cf. manflasensis West. (Figure 6.1), B. delicata West., Westermanniceras groeberi (West. and Ricc.), ?Leioceras sp. Early to Middle Aalenian, Opalinum and Early Murchisonae Zone.

24. Westermanniceras groeberi Assemblage Zone. Introduced by Westermann and Riccardi (see Riccardi et al., 1990b, 2000; Riccardi, 2000), and represented thoughout west-central Argentina, with W. groeberi (West. and Ricc) (Figure 6.2), Planammatoceras cf. planiforme Buck., Podagrosiceras athleticum Maub. and Lamb., Tmetoceras spp. Middle Aalenian, Murchisonae Zone.

25. Malarguensis Standard Zone. Introduced by Westermann and Riccardi (see Riccardi et al., 1990b, 2000; Hillebrandt et al., 1992), includes from below, the Subzones of Puchenquia compressa and P. mendozana and the Podagrosiceras maubeugei Horizon. Widespread in west-central Argentina, with Puchenquia (P.) 


\begin{tabular}{|c|c|c|}
\hline STAGES & STANDARD ZONES & ARGENTINA \\
\hline \multirow{4}{*}{ 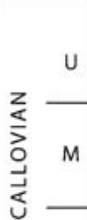 } & LAMBERTI & \multirow[b]{2}{*}{$?$} \\
\hline & ATHLETA & \\
\hline & CORONATUM & \multirow{2}{*}{ 36. R. patagoniensis } \\
\hline & JASON & \\
\hline \multirow{2}{*}{ L } & GRACILIS / CALLOVIENSE & 34. BODENBENDERI \\
\hline & BULLATUS & 33. VERGARENSIS \\
\hline \multirow{6}{*}{$\begin{array}{l}z \\
\mathbf{x} \\
\bar{z} \\
0 \\
\underline{T} \\
\frac{1}{\alpha} \\
\infty\end{array}$} & $\begin{array}{l}\text { DISCUS } \\
\text { RETROCOSTATUM }\end{array}$ & 32. STEINMANNI \\
\hline & BREMERI & \multirow{5}{*}{$\begin{array}{l}\text { 31.Cadomites - } \\
\text { Tulitidae }\end{array}$} \\
\hline & MORRISI & \\
\hline & SUBCONTRACTUS & \\
\hline & PROGRACILIS & \\
\hline & AURIGERUS & \\
\hline $\mathrm{L}$ & ZIGZAG & 30 Mulisano o. \\
\hline \multirow{7}{*}{ 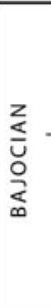 } & PARKINSONI & Lobosphinctes \\
\hline & GARANTIANA & \multirow{2}{*}{ 29. ROTUNDUM } \\
\hline & NIORTENSE & \\
\hline & HUMPHRIESIANUM & 28. HUMPHRIESIANUM \\
\hline & PROPINQUANS & \multirow[t]{2}{*}{ 27. GIEBELI } \\
\hline & LAEVIUSCULA & \\
\hline & DISCITES & 26. SINGULARIS \\
\hline \multirow{3}{*}{ 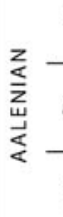 } & CONCAVUM & 25. MALARGUENSIS \\
\hline & MURCHISONAE & 24. W. groeberi \\
\hline & OPALINUM & 23. B. manflasensis \\
\hline
\end{tabular}

Figure 5 Correlation chart for the Middle Jurassic of westcentral Argentina.

malarguensis (Burck.) (Figure 6.3), P. (Gerthiceras) compressa West. and Ricc., P. (G.) mendozana West. and Ricc., Planammatoceras (Pseudaptetoceras) klimakomphalum (Vacek), P. (P.) tricolore West. and Ricc., P. gerthi (Jaw.), Eudmetoceras amplectens (Buckman), Csernyeiceras moerickei (Jaw.), Euhoploceras amosi West. and Ricc., Podagrosiceras athleticum Maub. and Lamb., Praeleptosphinctes jaworskii West. Late Aalenian to earliest Bajocian, Concavum to Early Discites Zones.

\section{Bajocian}

26. Singularis Standard Zone. Widespread in west-central Argentina. With Pseudotoites singularis (Gottsche) (Figure 6.4), $P$. sphaeroceroides (Tornq.), P. crassus West. and Ricc., P. transatlanticus (Tornq.), P. argentinus Arkell, Sonninia (Euhoploceras) amosi West. and Ricc., S. (Fissilobiceras) zitteli (Gott.), S. (Papilliceras) espinazitensis altecostata Tornq. Early Bajocian, Late Discites and Early Laeviuscula Zones. The regional Bajocian stratotype was defined (Westermann and Riccardi, 1989) at the base of this zone at cerro Puchenque, Mendoza province.

27. Giebeli Standard Zone. Widespread in west-central Argentina, it includes, from below, the subzones of E.g. submicrostoma and E. multiformis, and the Dorsetensia blancoensis Horizon. With E. (E.) multiformis (Gott.), E. (E.) aff. brochii (Sow.), E. (E.) vagabunda Buck., E. (Chondromileia) giebeli (Gott.) (Figures 6.5-6), Chondroceras recticostatum West. and Ricc., Stephanoceras (Skirroceras) cf. macrum (Quenst.), Sonninia (P.) espinazitensis Tornq., Witchellia sp., Dorsetensia mendozai West. and Ricc., D. blancoensis West. and Ricc. Early Bajocian, Late Laeviuscula and Propinquans Zones.

28. Humphriesianum Standard Chronozone. The originally European standard zone was extended to northern Chile (see Riccardi et al., 1990b, 2000) where it includes, from below, the sub- zones of Dorsetensia romani, Stephanoceras chilense and Duashnoceras chilense. It is rare in west-central Argentina, with Stephanoceras (S.) pyritosum (Qu.) (Figure 6.7), S. (Stemmatoceras) aff. frechi (Renz), Duashnoceras paucicostatum chilense (Hill.), Teloceras crikmayi chacayi West. and Ricc., Dorsetensia romani (Oppel), D. liostraca (Buckman).

29. Rotundum Standard Chronozone. Introduced for North America, was recognized in the Andes by Westermann and Riccardi (see Riccardi et al.,1990b, 2000), is rare in west-central Argentina, where it is present with Megaspaheroceras magnum Ricc. and West. (Figure 6.8), Cadomites cf. daubenyi (Gemm.), C. aff. deslongchampsi (d'Orb.), and Leptosphinctes sp. Late Bajocian, Niortense to Garantiana Zones. Beds correlative to the Parkinsoni Zone are probably present as indicated by the presence of Lobosphinctes intersertus Buck., a species typical of the English Upper Bajocian Parkinsoni Zone, but extending into the Lower Bathonian.

\section{Bathonian}

30. Morphoceras gulisanoi Assemblage Zone. This assemblage, defined by Riccardi and Westermann (1999) and Riccardi et al. (2000), is typically developed in Sierra de Reyes (c. $37^{\circ} \mathrm{S}, 69^{\circ}$ $45^{\prime} \mathrm{W}$ ), and probably occurs in Chacay Melehue (c. $37^{\circ} 15^{\prime} \mathrm{S}, 70^{\circ} 30^{\prime}$ W), above the Rotundum Zone. The M. gulisanoi assemblage is characterized by M. gulisanoi Ricc. and West. (Figures 6.9-10), Procerites cf. schloenbachi (de Grossouvre), Oxycerites cf. aspidoides (Rollier). Early Bathonian, Zigzag Zone.

31. Cadomites-Tulitidae Mixed Assemblage. Defined by Riccardi et al. (see 1990b) for a partially reworked fauna found in Chacay Melehue. Includes Cadomites ex gr. orbignyi (De Gross.) and bremeri Tsereteli, C. ex gr. rectelobatus (Hauer) (Figure 6.11), occurring with Tulites (Rugiferites?) cf. davaiacensis (Liss.), a species known from the Middle Bathonian, and Bullatimorphites (Kheraiceras) cf. bullatus (Orb.), and Choffatia (Homoeoplanulites) ex gr. aequalis (Roem.), indicating the Upper Bathonian. Similar ammonites were reported from northern Chile by Gröschke and Hillebrandt (1994) and placed in the Middle Bathonian Rugiferites sofanus Assemblage Zone. Middle to Late Bathonian.

32. Steinmanni Standard Zone. Defined by Riccardi et al. (see 1990b) at Chacay Melehue, Neuquen province. The lower part is characterized, besides the index species (Figure 6.12), by Choffatia (Homoeoplanulites) ex gr. aequalis (Roem.), Iniskinites crassus, I. gulisanoi, Ricc. and West., and the upper part, i.e. the Stehnocephalites gerthi Horizon, by S. gerthi (Spath), L. australis Ricc. and West. Xenocephalites cf. araucanus (Burck.), Neuqueniceras (N.) steinmanni Stehn, N. (N.) biscissum (Stehn), Oxycerites obsoletoides Ricc. et al., Choffatia jupiter (Stein.). Late Bathonian, Retrocostatum and Discus Zones. A possible distinction (see Parent 1998) of two additional horizons, of I. gulisanoi and I. crassus, for the lower and middle part of the zone respectively, is not adequately substantiated as the stratigraphic ranges of several species are wrongly quoted.

\section{Callovian}

Callovian ammonite assemblages of the Andes were defined, described and figured (see Riccardi et al. 1990b, 1994). The age of the Bathonian - Callovian boundary was directly dated in Chacay Melehue, from a level between the Steinmanni and Vergarensis zones. A tuff layer located at this boundary yielded a zircon date of $160.5 \pm 0.3$ (Odin et al., 1992).

33. Vergarensis Standard Zone. Typically represented in Chacay Melehue, with Eurycephalites vergarensis (Burck.) (Figures 6.13-14), Neuqueniceras (N.) steinmanni Stehn, Xenocephalites gottschei (Tornq.). Earliest Callovian. The alleged inclusion of $E$. vergarensis and $X$. gottschei in a single dimorphic pair and a change in the name of this zone (see Parent,1998), is questionable, as raw data were not given, relationships between macro- and microconch phragmocones are not evident, stratigraphic ranges differ for both species, and material from type localities was not considered. The 


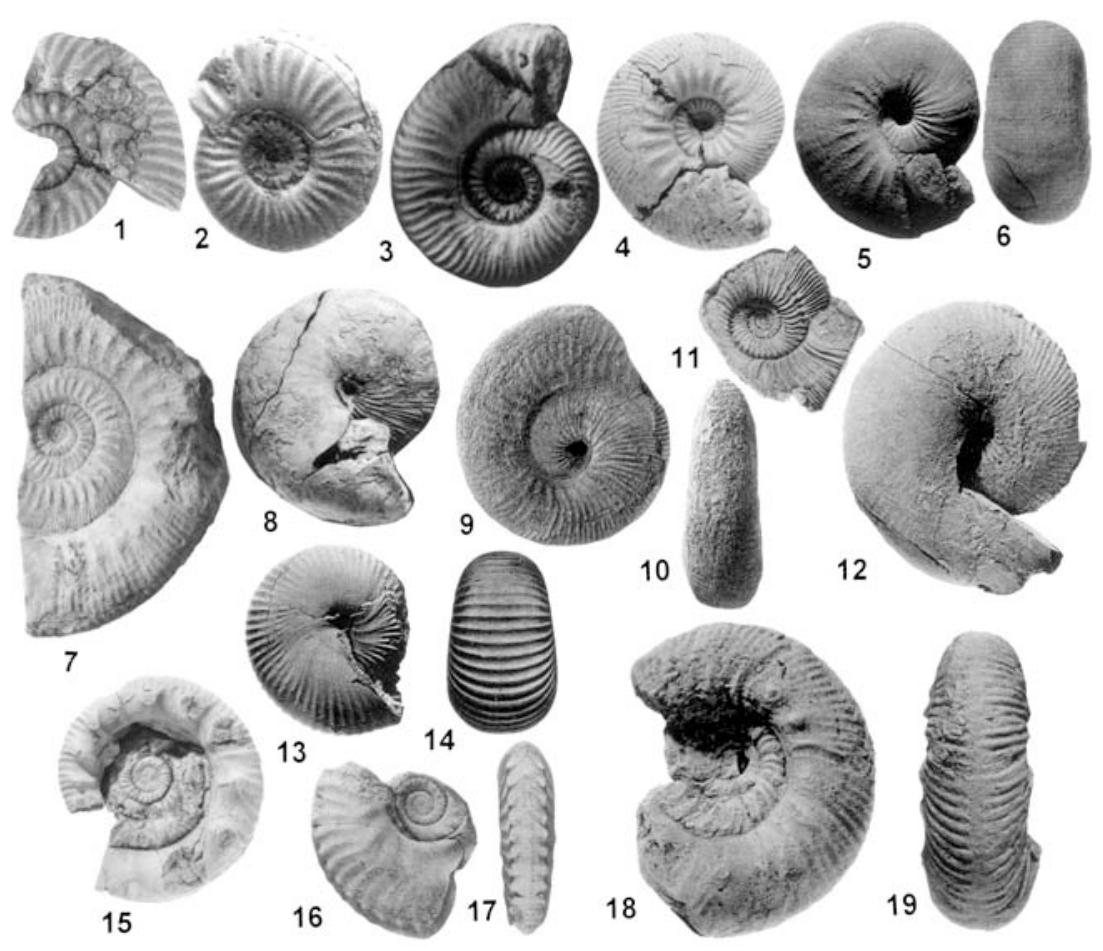

Figure 6 Middle Jurassic ammonites. Aalenian: 1, Bredyia $c f$. manflasensis West. (MLP 24502), 2. Westermanniceras groeberi (West. and Ricc.) (MLP 25536), 3, Puchenquia malarguensis (Burck.) (MLP12228); Bajocian: 4, Pseudotoites singularis (Gottsche) (SEGEMAR 349b), 5-6, Emileia (Chondromileia) giebeli (Gottsche) (MLP 12547), 7, Stephanoceras (S.) pyritosum (Quenstedt) (MLP 10666), 8, Megaspaheroceras magnum Ricc. and West. (MLP 23931); Bathonian: 9-10, Morphoceras gulisanoi Ricc. and West. (MLP 20043), 11, Cadomites ex gr. rectelobatus (Hauer) (MLP 21166), 12, Lilloettia steinmanni (Spath) (MLP 12703); Callovian: 13-14, Eurycephalites vergarensis (Burck.) (MLP 12658), 15, Neuqueniceras (Frickites) bodenbenderi (MLP 23997), 16-17, Hecticoceras (H.) proximum Elmi (MLP 12808), 18-19, Rehmannia (Loczyceras) patagoniensis (Weaver) (MLP 23986). Repositories: MLP, Museo de la Plata; SEGEMAR, Argentine Geological Survey. All figures $\times 0.28$, except $2,3, \times 0.56,8, \times 0.176$ and $15, \times 0.215$.

regional Callovian stratotype was defined (Westermann and Riccardi, 1989) at the base of this zone at Chacay Melehue.

34. Bodenbenderi Standard Zone. Defined at Chacay Melehue, Neuquen province, with Neuqueniceras (Frickites) bodenbenderi (Tornq.) (Figure 6.15), Eurycephalites rotundus (Tornq.), E. extremus (Tornq.), Xenocephalites stipanicici Ricc. et al., X. involutus Ricc. and West. Early Callovian, latest Bullatus and Gracilis Zones.

35. Proximum Standard Zone. Defined at Chacay Melehue, with Hecticoceras $(H$.$) proximum Elmi (Figures 6.16-17), H. (H.)$ cf. hecticum (Rein.), H. (H.) boginense (Pet.), H. (Chanasia) navense Román, $H$. (Ch.) ardescicum Elmi, Xenocephalites stipanicici Ricc. et al., X. involutus Ricc. and West., Neuqueniceras (Frickites) cf. antipodum (Gott.), Rehmannia (R.) cf. paucicostata (Tornq.), R. (R.) brancoi (Stein.), R. (R.) stehni (Zeiss), Oxycerites (Paroxycerites) oxynotus (Leanza). Early Callovian, late Gracilis Zone.

36. Rehmannia patagoniensis Horizon. Horizon with abundant $R$. (Loczyceras) patagoniensis (Weaver) (Figures 6.18-19), typically represented in near-shore facies along the eastern margin of the Neuquen Basin. The presence (Parent et al., 2006b, p. 309; Parent, 2006) in Chacay Melehue of this and other supposedly associated taxa, needs to be adequately substantiated, as it is in contradiction with a well documented biostratigraphy (see Riccardi et al., 1994), and could be due to a misconception of the species. Middle Callovian, Jason and Coronatum Zones.

\section{Upper Jurassic}

\section{Oxfordian}

Marine Oxfordian is well represented in westcentral Argentina, although with a relatively poorly preserved ammonite fauna (see Riccardi et al., 1990c), mostly restricted to Middle Oxfordian levels of La Manga Formation. Late Callovian - Early Oxfordian and Late Oxfordian faunas are not usually present, due to regional hiatus, or are geographically restricted and poorly preserved. This situation and frequent absence of precise information on stratigraphic procedence has hindered most attempts to refine the Late Callovian-Oxfordian stratigraphy (cf. Parent, 2006).

37. Peltoceratoides-Parawedekindia Assemblage Zone. Defined in Riccardi et al. (1990c), is present (unpublished) in part of the Neuquen Basin, with Peltoceratoides sp. (Figure 8.1) and Parawedekindia sp. As "P. pressulus Biozone" in Parent (2006). Latest Callovian to Early Oxfordian, latest Lamberti to Early Cordatum Zones.

38. Perisphinctes-Araucanites Assemblage Zone. This assemblage (Riccardi et al., 1990c) is widespread throughout the Neuquen Basin, and is equivalent to the "Subvinalesphinctes pseudokranaus, Passendorferia and Euaspidoceras tarapacaense Biozones" of Parent (2006). It includes $P$. (Kranaosphinctes) spp., P. (Arisphinctes) spp. (Figure 8.4), "Perisphinctes" spp., Araucanites mulai, A. reyesi, A. stipanicici (Figures 8.2-3), West. and Ricc., Euaspidoceras ajax Leanza, E. aff. waageni Spath. Latest Early and Middle Oxfordian, Latest Cordatum to Transversarium (?and Bifurcatum) Zones.

39. Lithacosphinctes Horizon. Representatives of Lithacosphinctes Oloriz were first described from northern Chile and used (Parent, 2006) to define a " $L$. desertorum Biozone", and appear to be present (Figure 8.5) in basinal facies of the Neuquen Basin (Parent et al., 2006b). Late Oxfordian, Bimammatum (to Planula) Zone(s).

\section{Kimmeridgian}

In west-central Argentina the uppermost Oxfordian and Kimmeridgian consists of continental facies. Only in the Austral Basin, southern Argentina, some poorly preserved ammonites have been tentatively dated as Late Kimmeridgian.

\section{Tithonian}

In west-central Argentina, the base of the Mendoza Group has yielded a rich Tithonian ammonite fauna (see Riccardi et al. 1990c). A poorly preserved fauna of similar age is also present in southern Patagonia (see also Kraemer and Riccardi, 1997). A detailed zonal scheme (see below) was developed for west-central Argentina. Successive changes (Parent, 2001, 2003; Parent et al., 2006a) to the ammonite systematics and biostratigraphy await substantiation on a thorough systematic study of new and extensive field collections.

40. Virgatosphinctes mendozanus Assemblage Zone. Zone proposed by Burckhardt (see Leanza, 1980), characterizes the base of the Vaca Muerta Formation and marks the initiation of a new marine sedimentary cycle following the Kimmeridgian continental facies of the Tordillo Formation. With: $V$. mendozanus (Burck.), $V$. andesensis (Douv.), V. denseplicatus rotundus Spath, V. evolutus Leanza, V. mexicanus (Burck.), V. burckhardti (Douv.), Pseudinvoluticeras douvillei Spath, P. windhauseni (Weav.), P. (?) wilfridi (Douv.), Choicensisphinctes choicensis (Burck.) (Figures 8.6-7), Ch. erinoides (Burck.), Subplanites malarguensis Spath. Latest Early to Middle Tithonian, Darwini to Semiforme Zones. 


\begin{tabular}{|c|c|c|}
\hline STAGES & STANDARD ZONES & ARGENTINA \\
\hline \multirow{5}{*}{ 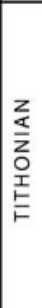 } & DURANGITES & \multirow{2}{*}{$\begin{array}{r}\text { 45. S. koeneni } \\
\text { 44. C. alternans }\end{array}$} \\
\hline & MICROCANTHUM & \\
\hline & PONTI & 43. W. intermispinosum \\
\hline & FALLAUXI & 42. A. proximus \\
\hline & & \multirow{3}{*}{ 40. V. mendozanus } \\
\hline & SEMIFORME & \\
\hline \multirow{2}{*}{ L } & DARWINI & \\
\hline & HYBONOTUM & \\
\hline \multirow{6}{*}{ 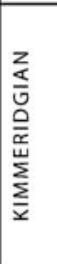 } & BECKERI & \\
\hline & EUDOXUS & \\
\hline & ACANTHICUM & \\
\hline & DIVISUM & \\
\hline & HYPSELOCYCLUM & \\
\hline & PLATYNOTA & \\
\hline \multirow{7}{*}{ 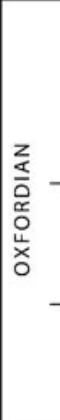 } & PLANULA & \\
\hline & BIMAMMATUM & \multirow{2}{*}{ 39. Lithacosphinctes } \\
\hline & BIFURCATUM & \\
\hline & TRANSVERSARIUM & \multirow{3}{*}{$\begin{array}{l}\text { 38. Perisphinctes - } \\
\text { Araucanites }\end{array}$} \\
\hline & PLICATILIS & \\
\hline & CORDATUM & \\
\hline & MARIAE & $\begin{array}{l}\text { 37. Peltoceratoides - } \\
\text { Parawedekindia }\end{array}$ \\
\hline
\end{tabular}

Figure 7 Correlation chart for the Upper Jurassic of west-central Argentina.

41. Pseudolissoceras zitteli Assemblage Zone. Zone introduced by Burckhardt (see Leanza, 1980). Widespread in west-central Argentina. With P. zitteli (Burck.) (Figures 8.8-9), $P$. pseudoolithicum (Haupt), Glochiceras steueri Leanza, Hildoglochiceras wiedmanni Leanza, Parastreblites comahuensis Leanza, Aspidoceras cieneguitense (Steuer), Pseudhimalayites steinmanni (Steuer), Simocosmoceras adversum andinum Leanza and Oloriz. Early Middle Tithonian, Semiforme to Fallauxi Zones.

42. Aulacosphinctes proximus Assemblage Zone. Zone proposed by Burckhardt (see Leanza, 1980). Widespread in west-central Argentina, with A. proximus (Steuer) (Figures 8.10-11), Subdichotomoceras sp., Pseudhimalayites steinmanni (Steuer), Aspidoceras andinum (Steuer), A. neuquensis Weaver. The proposed inclusion (Parent, 2003) of A. proximus (Steuer) in Torquatisphinctes Spath is ill-founded, as are several other related assumptions which require re-examination, e.g. the supposed presence of tubercles in the inner whorls of Aulacosphinctes Uhlig, the resemblance of $A$. proximus to some Mexican material, compared with Subdichtomoceras inversum (Spath) and Aulacosphinctoides lauri (Aguilera) and A. potosinus (Aguilera), and included by Parent (2003) in Torquatisphinctes. Middle Tithonian, Fallauxi to Ponti Zones.

43. Windhauseniceras internispinosum Assemblage Zone. Zone introduced by Weaver (see Leanza, 1980), Vaca Muerta Formation, widespread in west-central Argentina. With $W$. internispinosum (Krantz) (Figures 8.12-13), Wichmanniceras mirum Leanza, Pachysphinctes americanensis Leanza, Hemispiticeras aff. steinmanni (Steuer), Subdichotomoceras araucanense Leanza, S. windhauseni (Weaver), Parapallasiceras aff. pseudocolubrinoides Oloriz, $P$. aff. recticosta Oloriz, Aulacosphinctoides aff. hundesianus (Uhlig), Aspidoceras euomphalum Steuer, Corongoceras lotenoense Spath (Figures 8.14-15). In the Los Catutos Member, Leanza and Zeiss (see 1992,1994) recognized, from below, the Catutosphinctes rafaeli Leanza and Zeiss and Zapalia fascipartita Leanza and Zeiss Subzones, the latter including the
Aspidoceras aff. altum Biro and the Djurjuriceras catutosense Leanza and Zeiss horizons. Latest Middle Tithonian, Ponti Zone.

44. Corongoceras alternans Assemblage Zone. Zone proposed by Leanza (see Leanza, 1980). It is known in the Vaca Muerta and equivalent formations and is well represented in west-central Argentina. With C. alternans (Gerth), C. mendozanum (Behr.), C. rigali Leanza, Aulacosphinctes mangaensis (Steuer), Lytohoplites burckhardti Spath, Micracanthoceras tapiai Leanza, M. lamberti Leanza, Berriasella australis Leanza, B. pastore $i$ Leanza, B. krantzi Leanza, B. bardensis Krantz, Chigaroceras gerthi (Krantz). Late Tithonian, Microcanthum and Durangites spp. Zones.

45. Substeueroceras koeneni Assemblage Zone. Proposed by Gerth (see Leanza 1981). With the same geographic extension than the underlying zones. With S. koeneni (Steuer) (Figures 8.16-17), S. exstans Leanza, Aulacosphinctes azulensis Leanza, A. mangaensis (Steuer), Pectinatites (?) striolatus (Steuer), Berriasella fraudans inflata Leanza, B. inaequicostata Gerth, Parodontoceras calistoides (Behr.), Aspidoceras longaevum Leanza, Blanfordiceras vetustum (Steuer), Himalayites andinus H. Leanza, Spiticeras acutum Gerth, Traditionally ascribed to the Upper Tithonian (see Leanza, 1981), probably reaches the lower Berriasian as indicated by the occurrence at its top of Schaireria longaeva Leanza and "Spiticeras" acutum Gerth, a probable forerunner of Groebericeras Leanza (see Zeiss, 1986; Leanza, 1996). Late Tithonian-early Middle Berriasian, Durangites spp.-Jacobi/Grandis and earliest Occitanica Zones).

\section{Neuquen Basin: major paleogeographic, sedimentary and faunal patterns}

The origin of Mesozoic rocks in southern South America is related to the Late Triassic and Early Jurassic extensional tectonics which affected the western margin of Gondwana, and formed a series of fault-bounded, NNW-striking grabens. In these grabens volcanic and volcaniclastic rocks were accumulated, together with continental and, locally, marine sediments. In the Rio Atuel area a Rhaetian-Sinemurian Pacific marine corridor opened, and subsequent widespread subsidence lead to full development of a back-arc basin, i.e. the Neuquén Basin.

Changes in sea level related to eustatic subsidence and sediment influx resulted in a succession of depositional sequences (see Legarreta and Gulisano 1989), bounded by discontinuities, associated with important paleogeographic changes. These sequences have been grouped in several "mesosequences", i.e. Cuyo (max. thick. c. $3000 \mathrm{~m}$, incl. sequences C1-7), Lotena-Chacay (max. thick. c. 800 $\mathrm{m}$, incl. sequences L1-5), and Lower Mendoza (max. thick. c. 3800 $\mathrm{m}$, incl. sequences M1-6). There is an apparent relationship between sequences and the distribution and abundance of ammonites (see Riccardi et al., 1994). Thus ammonite faunas are more widespread and diverse in the middle to upper part of the sequences, whilst geographic restriction and low diversity occur close to their boundaries (Figure 9).

The first Jurassic marine encroachment occurred north of $40^{\circ} \mathrm{S}$ (Figure 1), where the Rhaetian-Hettangian-Sinemurian sea covered coastal areas of Chile reaching as far east as the Río Atuel area (see Riccardi et al. 2004; Lanes, 2005). As a result basinal to shelf pelites and sandstones were deposited, which are absent toward the south, where marine deposition began in the Pliensbachian. The maximum expansion eastward of the Early Jurassic sea was attained in the late Early Pliensbachian. With sea-level lows turbiditic deposits (Los Molles Formation) were formed in the basinal area, and with sealevel highs, outer-shelf pelites (Los Molles Formation), littoral sandstones (Puesto Araya Formation), and continental facies (El Freno Formation). A Late Pliensbachian- Toarcian sea-level fall was punctuated by a late Early Toarcian rise.

This pattern agrees quite well with changes in ammonite diversity (considered as a simple measure of genera number) (Figure 9). Thus diversity is quite low in the Hettangian, and shows a rise in the 


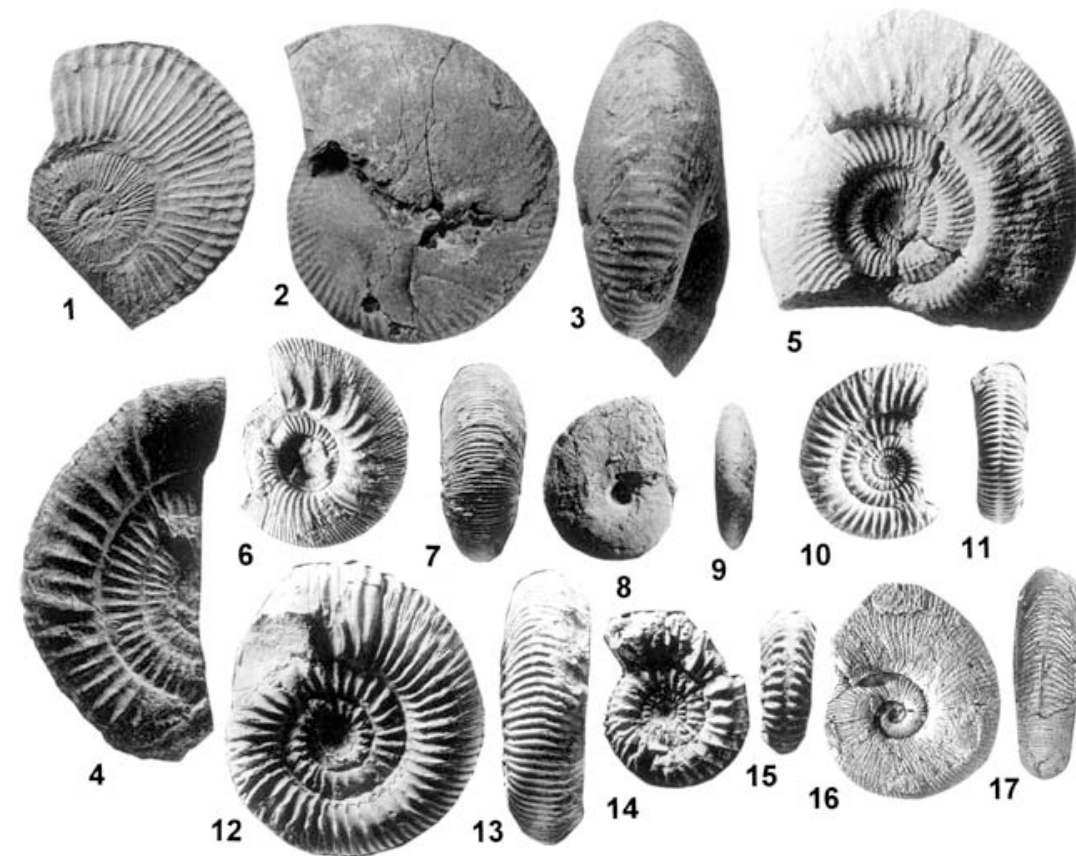

Figure 8 Upper Jurassic ammonites. Oxfordian: 1, Peltoceratoides pressulus (Leanza) (SEGEMAR s/n), 2-3, Araucanites stipanicici West. and Ricc. (MLP 12240); 4, Perisphinctes (Arisphinctes) sp., 5, Lithacosphinctes aff. janus (Choffat) (LPB 426); Tithonian: 6-7, Choicensisphinctes choicensis (Burck.) (SEGEMAR 8905/3); 8-9, Pseudolissoceras zitteli (Burck.) (SEGEMAR 7333/1); 10-11, Aulacosphinctes proximus (Steuer) (GPIT 1545/3); 12-13, Windhauseniceras internispinosum (Krantz) (SEGEMAR 8941/1); 14-15, Corongoceras lotenoense Spath (SEGEMAR 8940/1); 16-17, Substeueroceras koeneni (Steuer) (MLP 3362). Repositories: GPIT, Institut Geologie Paläontol. Tübingen; LPB, Universidad Nacional de Rosario; MLP, Museo de la Plata; SEGEMAR, Argentine Geological Survey. 1, modified from Leanza 1947; 4, modified from Stipanicic, 1951; 5, modified from Parent et al., 2006b; 6-15, modified from Leanza, 1980. All figures $\times 0.28$.

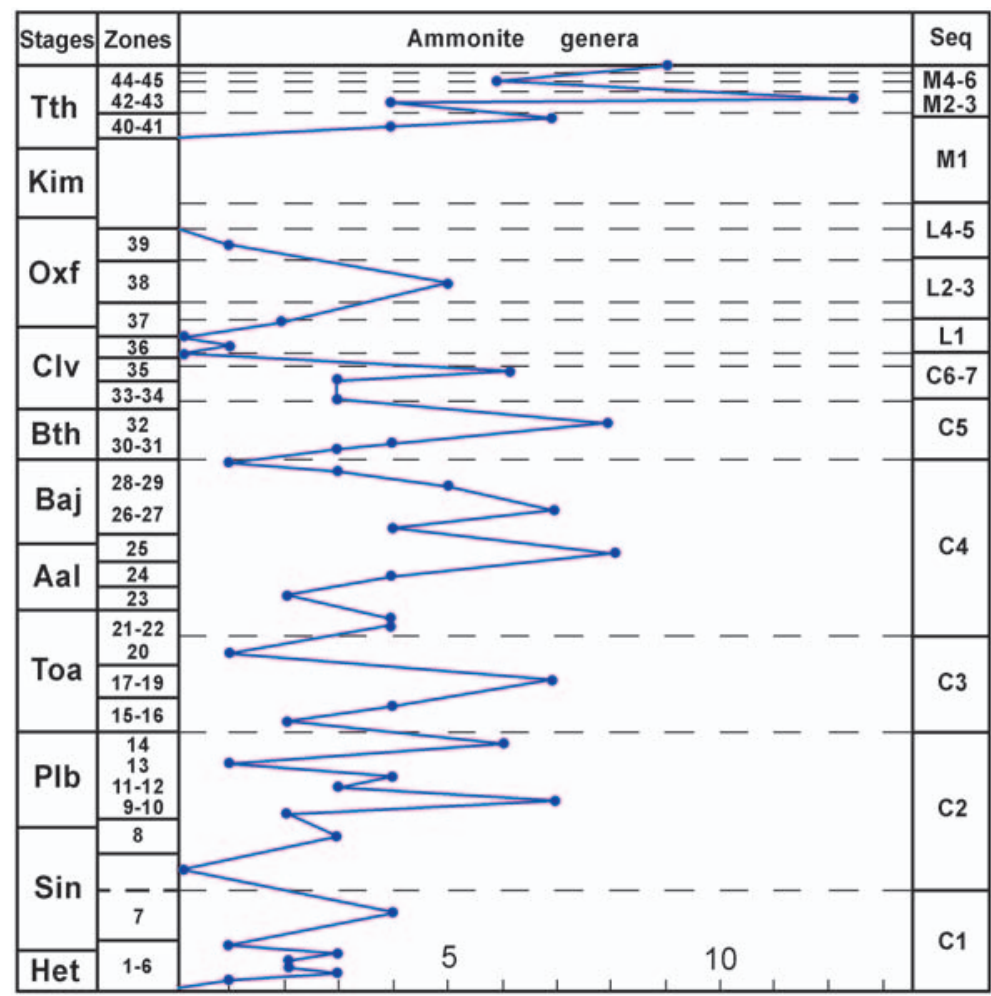

Figure 9 Jurassic ammonite diversity (genera) in the Neuquen Basin (For Zones 1-45 see Figs. 3, 5, and 7; for Seq. C1-C5, L1-L5 and M1-M6 see text). early Sinemurian-although this rise could also be an artifact due to a poorly defined biostratigraphy. Subsequently there was a progressive increase in diversity from the late Sinemurian to the early Pliensbachian $(M$. externum Zone, Late Jamesoni and Early Ibex Zones), with a maximum, characterized by high endemism (calculated as $40 \%$ with, or $80 \%$ without cosmopolitan taxa), coinciding with the middle part of sequence $\mathrm{C} 2$, followed by a sharp fall to the early-late Pliensbachian boundary ( $F$. fannini Zone, late Davoei to early Margaritatus Zones), punctuated by a slight rise in the $A$. behrendseni Zone (middle Davoei Zone). Thereafter there is a further rise at the end of the Pliensbachian $(F$. disciforme Zone, Spinatum Zone), followed by a pronounced fall at the beginning of the Toarcian (Tenuicostatum $\mathrm{Z}$ ), and a final rise to a maximum at the end of the early Toarcian $(P$. largaense- $C$. chilense Zones, Serpentinum to Bifrons Zones), coinciding with the middle part of sequence C3. Subsequently there is a marked fall, with a slight intervening rise, across the Toarcian-Aalenian boundary.

During the Middle Jurassic parts of the western volcanic arc became continental, with subaerial volcanism. To the east, marine sedimentation was continuous in the back-arc basin. During the Aalenian the shelf-margin moved basinward, and the area of turbidite deposition was reduced to a brief, low-sea-level stage, with low ammonite diversity, in the early Aalenian. A transgressive maximum occurred during the Bajocian, when a sea-level rise expanded the shelf area and high clastic input from the south and east resulted in deltaic progradation (Lajas Formation; sequence C4). Ammonite diversity (Figure 9) shows a marked rise throughout the Aalenian, to reach a maximum in the Malarguensis Zone ( $\approx$ Concavum-Discites Zones), Aalenian-Bajocian boundary, followed by a slight fall at the boundary between the Malarguensis and Singularis zones $(\approx$ Laeviuscula Zone) and a further slight rise in the Giebeli A.Z. ( $\approx$ Propinquans Zone). Both maxima coinciding with the middle part of sequence $\mathrm{C} 4$.

As a result of an important sea-level fall a regional regression occurred during most of the Bathonian in west-central Argentina, so that in marginal areas between $26^{\circ} \mathrm{S}$ and $37^{\circ} \mathrm{S}$ the Callovian rests directly on Bajocian or older strata. Ammonite diversity (Figure 9) shows a sharp drop across the Bajocian- Bathonian boundary, followed by a marked rise to a late Bathonian maximum in the Steinmanni Zone, in coincidence with the middle part of sequence $\mathrm{C} 5$.

The Bathonian regressive phase extended into the early Callovian when the basin became strongly restricted, and evaporites were deposited (sequences C67). Ammonite diversity (Figure 9) shows a decline across the Bathonian-Callovian boundary, followed by a slight rise at the end of the early Callovian. During the late Callovian there was a sharp sea-level fall, the shelf areas were partially eroded, and in the deepest areas fluvial and aeolian continental sandstones and conglomerates were deposited (sequence L1), although a short sealevel rise occurred during the middle-late Callovian producing a renewed short trangression with a marked expansion of the area of marine sedimentation which, however, did not reach the extent of the earlier Bajocian sea. The Rehmannia patagoniensis Horizon thus transgresses over evaporites, deltaic, and even continental facies of different ages of the Lower-Middle Jurassic.

During the early Oxfordian, as a result of a sealevel rise, a turbiditic succession developed in the Andean area, followed by pelites that transgressed the shelf area (sequence L2). Toward the end of this stage, 
prograding carbonates developed (La Manga Formation, sequence L3), followed in the late Oxfordian, by evaporitic sedimentation in the central parts of the basin (Auquilco Formation, sequences L4-5). Ammonite diversity (Figure 9) shows a more or less uniform increase from the beginning of the Oxfordian to reach a maximum in the Perisphinctes-Araucanites Zones $(\approx$ Plicatilis and Tansversarium Zones), followed by a marked fall.

The progressive shallowing of basins of west-central Argentina during the Callovian-Oxfordian was due to a general sea-level fall related to marked uplift of the volcanic arc of the Coastal Cordillera of Chile, which acted as a source of clastics and volcanics. The resulting deposition from the west and displacement of the basin axis to the east climaxed during the Kimmeridgian, when the volcanism reached the Principal Cordillera. The marginal areas were sites of strong erosion, and deposition occurred in other parts of the basin. Thus, a complex setting of continental deposits was developed, i.e. Tordillo Formation and equivalents.

The area was again flooded during the Tithonian-Early Cretaceous by a new major transgression. In the middle early Tithonian, a sea-level rise caused fast submergence of the basin and strong expansion of the marine area, with deposition of marls and bituminous limestones (Vaca Muerta Formation). Deposition of littoral sandstones was restricted to some marginal areas. During the late Tithonian, as a result of strong progradation of clastic carbonates from the south and east, the area of marine sedimentation became restricted, and marginal and continental facies became widespread. Ammonite diversity (Figure 9) shows a sharp increase from the Early (V. mendozanus Zone $\approx$ late Darwini Zone) to the Middle Tithonian ( $W$. internispinosum Zone $\approx$ Ponti Zone), with a slight fall in the A. proximus Zone, i.e. across the Fallauxi-Ponti boundary, followed by a sharp drop at the beginning of the late Tithonian, and another rise across the Tithonian-Berriasian boundary.

\section{Acknowledgements}

Financial support was provided by the Consejo Nacional de Investigaciones Científicas y Técnicas (PIP 5635) and Agencia Nacional de Promoción Científica y Tecnológica (PICT 07-26236), Argentina. B.A.P.Wimbledon and S. Turner made useful comments to improve this paper. This is a contribution to IGCP 506 "Jurassic Boundary Events".

\section{References}

Alvarez, P., 1996. Los depósitos triásicos y jurásicos de la Alta Cordillera de San Juan. Dirección Nacional del Servicio Geológico, Anales, v. 24, pp. $59-137$.

Gröschke, M. and Hillebrandt, A. v., 1994. The Bathonian in northern Chile. Geobios, M.S. v. 17 , pp. 255-264.

Hillebrandt, A. v., 1987. Liassic ammonite zones of South America and correlations with other provinces. With description of new genera and species of ammonites. In: Volkheimer, W., ed., Bioestratigrafía de los Sistemas regionales del Jurásico y Cretácico de América del Sur, pp. 111-157. Mendoza.

Hillebrandt, A. v, 2000. Die Ammoniten-Fauna des sudamerikanischen Hettangium (basaler Jura), Teil I, II, III, Palaeontographica, v. A257, pp. 85-189, v. A258, pp. 1-64, 65-116.

Hillebrandt, A.v., 2002. Ammoniten aus dem oberen Sinemurium von Sudamerika. Revue de Paléobioloegie, v. 21, pp. 35-147.

Hillebrandt, A.v., 2006. Ammoniten aus dem Pliensbachium (Carixium und Domerium) von Sudamerika. Revue de Paléobiologie, v. 25, pp. 1-403.

Hillebrandt, A.v., Smith, P., Westermann, G.E.G. and Callomon, J.H., 1992 Ammonite zones of the Circum-Pacific region. In: Westermann, G.E.G., ed., The Jurassic of the Circum-Pacific, pp. 247-272. Cambridge University Press, Cambridge.

Iglesia Llanos, M.P. and Riccardi, A.C., 2000. The Neuquen composite section: magnetostratigraphy and biostratigraphy of the marine lower Jurassic from the Neuquen basin (Argentina). Earth and Planetary Science Letters, v. 181 , pp. $443-457$.
Kraemer, P.E. and Riccardi, A.C., 1997. Estratigrafía de la región comprendida entre los lagos Argentino y Viedma (49 40' - 50 $10^{\prime}$ lat. S), Provincia de Santa Cruz. Revista de la Asociación Geológica Argentina, v. 52, pp. 333-360.

Lanés, S., 2005. Late Triassic to Early Jurassic sedimentation in northern Neuquén Basin, Argentina: Tectosedimentary Evolution of the First Transgression. Geologica Acta, v. 3, pp. 81-103.

Leanza, H. A., 1980. The Lower and Middle Tithonian Ammonite Fauna from Cerro Lotena, Province of Neuquen, Argentina. Zitteliana, v. 5, pp. 3-49.

Leanza, H.A., 1981. The Jurassic-Cretaceous boundary beds in West Central Argentina and their ammonite zones. Neues Jahrbuch fur Geologie und Palaontologie Abhandlungen, v. 161, pp. 62-92.

Leanza, H.A., 1996. Advances in the ammonite zonation around the Jurassic/Cretaceous boundary in the Andean Realm and correlation with Tethys. Jost Wiedmann Symposium, Abstracts: 215-219. Tübingen.

Leanza, H.A. and Blasco, G., 1990. Estratigrafía y ammonites pliensbachianos del area del arroyo Nireco, Neuquen, Argentina, con la descripcion de Austromorphites gen. nov. Revista de la Asociación Geológica Argentina, v.45, pp. 159-174.

Leanza, H.A. and Zeiss, A., 1992. On the ammonite fauna of the Lithographic Limestones from the Zapala region (Neuquén province, Argentina), with the description of a new genus. Zentralblatt für Geologie und Paläontologie Teil I, 1991, H.6, pp. 1841-1850.

Leanza, H.A. and Zeiss, A., 1994. The "Lithographic limestones" of Zapala (Central Argentina) and their Ammonite fauna. Geobios M.S., v.16, pp. $245-250$.

Legarreta, L. and Gulisano, C.A., 1989. Análisis estratigráfico secuencial de la Cuenca Neuquina (Triásico superior - Terciario inferior). Serie Correlación Geológica 6: 221-243.

Legarreta, L. and Uliana, M.A., 1996. The Jurassic succession in west-central Argentina: stratal patterns, sequences and paleogeographic evolution. Palaeogeography, Palaeoclimatology, Palaeoecology, v.120, pp. 303-330.

Odin, G.S., Baadsgaard, H., Hurford, A.J., and Riccardi, A.C., 1992. U-Pb and fission track geochronology of Bathonian-Callovian "tuffs" from Argentina. In: Odin, G.S., ed., Phanerozoic time scale. Bulletin de Liaison et Information, v. 11, pp. 11-17.

Ogg, J.G., 2004. Status of Divisions of the International Geologic Time Scale. Lethaia, v. 37, pp. 183-199.

Parent, H., 1998. Upper Bathonian and lower Callovian ammonites from Chacay Melehué, (Argentina). Acta Palaeontologica Polonica, v. 43, pp. 69-130.

Parent, H., 2001. The Middle Tithonian (Upper Jurassic) ammonoid fauna of Cañadón de los Alazanes, southern Neuquén-Mendoza Basin, Argentina. Boletín del Instituto de Fisiografía y Geología, v.71, pp. 19-38.

Parent, H., 2003. The ataxioceratid ammonite fauna of the Tithonian (Upper Jurassic) of Casa Pincheira, Mendoza (Argentina). Journal of South American Earth Sciences, v.16, pp. 143-165.

Parent, H., 2006. Oxfordian and Late Callovian ammonite faunas and biostratigraphy of the Neuquén-Mendoza and Tarapacá basins (Jurassic, Ammonoidea, western South America). Boletin del Instituto de Fisiografía y Geología 76(1-2): 1-70.

Parent, H., Scherzinger, A. y Schweigert, G., 2006a. The earliest ammonite faunas from the Andean Tithonian of the Neuquén-Mendoza Basin, Argentina. Neues Jahrbuch für Geologie und Paläontologie, Abhandlungen 241(2): 253-268.

Parent, H., Schweigert, G. and Melendez, G., 2006b. Oxfordian perisphinctid ammonites from Chacay Melehué, Argentina. Paläontologische Zeitschrift, v. 80, pp. 307-324.

Remane, J., 2000. International Stratigraphic Chart. International Union of Geological Sciences.

Riccardi, A.C., 1985. Los Eurycephalitinae andinos (Ammonitina, Jurásico medio): modelos evolutivos y resolución paleontológica. Boletín Genético, Instituto de Fitotecnia, v. 13, pp. 1-27.

Riccardi, A.C., 1991. Jurassic and Cretaceous Marine Connections between the Southeast Pacific and Tethys. Palaeogeography, Palaeoclimatology, Palaeoecology, v. 87, pp. 155-189.

Riccardi, A.C., 2000. The Podagrosiceratinae (Ammonitina) in the Upper Toarcian-Lower Bajocian (Jurassic) of Argentina, Revue de Paléobiologie, V.S., v.8, pp. 13-28.

Riccardi, A.C. 2005. First teuthid cephalopod from the Lower Jurassic of South America (Neuquén Basin, Argentina). In: Riccardi, A.C., ed., New insigths into the Juurassic record of South America (Andes and Patagonia). Geologica Acta 3(2): 179-184.

Riccardi, A.C. and Westermann, G.E.G., 1999. An early Bathonian Tethyan ammonite fauna from Argentina. Palaeontology, v. 42, pp. 193-209. 
Riccardi, A.C., Damborenea, S.E. and Mancenido, M.O., 1990a. The Lower Jurassic of South America and Antarctic Peninsula. Newsletter on Stratigraphy, v. 21, pp. 75-103.

Riccardi, A.C., Westermann, G.E.G. and Damborenea, S.E. 1990b. Middle Jurassic South America and Antarctic Peninsula. Newsletter on Stratigraphy, v. 21, pp. 105-128.

Riccardi, A.C., Leanza, H.A. and Volkheimer, W. 1990c. Upper Jurassic of South America and Antarctic Peninsula. Newsletter on Stratigraphy, v. 21, pp. 129-147.

Riccardi, A.C., Damborenea, S.E., Manceñido, M.O. and Ballent, S.C., 1991. Hettangian and Sinemurian (Lower Jurassic) biostratigraphy of Argentina. Journal of South American Earth Sciences, v. 4, pp. 159-170.

Riccardi, A.C., Gulisano,C.A., Mojica, J.,Palacios, O., and Schubert,C., 1992. Western South America. In: Westermann, G.E.G., ed., The Jurassic of the Circum Pacific, pp. 122-161. Cambridge Univ. Press, London.

Riccardi, A.C., Damborenea, S.E., Manceñido, M.O. and Ballent, S.C., 1994. Middle Jurassic biostratigraphy of Argentina. Geobios M.S., v. 17, pp. 423-430.

Riccardi, A.C., Leanza, H.A., Damborenea, S.E., Manceñido, M.O., Ballent, S.C. and Zeiss, A., 2000. Marine Mesozoic Biostratigraphy of the Neuquén Basin. Zeitschrift für Angewandte Geologie, SH 1(2000), pp. 103-108.

Riccardi, A.C., Damborenea, S.E., Manceñido, M.O. and Iglesia Llanos, M.P., 2004. The Triassic/Jurassic boundary in the Andes of Argentina. Rivista Italiana di Paleontologia e Stratigrafia, v. 110, pp. 69-76.

Stipanicic, P.N., 1996. Milestones in the Study of the Jurassic of Argentina. In: Riccardi, A.C., ed., Advances in Jurassic Research, pp. 23-42. Transtec Publications, Zurich.

Valencio, S.A., Cagnoni, M.C., Ramos, A.M., Riccardi, A.C. and Panarello, H.O., 2005. Chemostratigraphy of the Pliensbachian, Puesto Araya Formation (Neuquen Basin, Argentina). Geologica Acta, v. 3, pp. 147-154.
Vicente, J.-C., 2005. Dynamic paleogeography of the Jurassic Andean Basin: pattern of transgression and localisation of main straits through the magmatic arc. Revista de la Asociación Geológica Argentina, v. 60, pp. 221-250.

Vicente, J.-C., 2006. Dynamic paleogeography of the Jurassic Andean Basin: pattern of regression and general considerations on main features. Revista de la Asociación Geológica Argentina, v. 61, pp. 408-437.

Westermann, G.E.G. and Riccardi, A.C., 1989. Jurassic Stage boundaries in South America. International Subcommission on Jurassic Stratigraphy, Newsletter 19: 16-22.

Zeiss, A., 1986, Comments on a tentative correlation chart for the most important marine provinces at the Jurassic/Cretaceous boundary. Acta Geologica Hungarica, v. 29, pp. 27-30.

\begin{abstract}
Alberto C. Riccardi is a Professor and chair of the Division of Invertebrate Paleontology at the University of La Plata, Argentina. His research interest are principally in Jurassic and Cretaceous paleontology and stratigraphy, and history and philosophy of geological sciences.
\end{abstract}

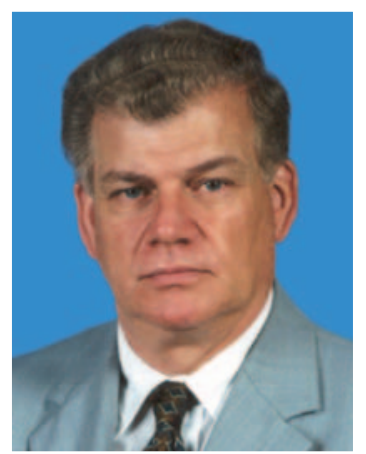

\section{Hutchison 'Young Scientist' Fund}

William Watt Hutchison, "Hutch" to his many friends around the world, was a Scots-born Canadian geologist who served Canada and the IUGS in myriad dynamic and creative ways. Most notably, he served as the IUGS Secretary General (1976-1980) at a pivotal time in its history, and as IUGS President (1984-1987). The same boundless energy, enthusiasm, skill in communications, and ability to foster teamwork that characterized his work with the IUGS also carried him to preeminent scientific administrative positions in the Canadian Government, where he served as Director General of the Geological Survey of Canada and as Assistant Deputy Minister of Earth Sciences. His distinguished career was terminated in 1987 by his untimely death at the age of 52, following a painful struggle with cancer.

One of Hutch's last wishes was to establish under IUGS auspices a memorial foundation intended to promote the professional growth of deserving, meritorious young scientists from around the world by supporting their participation in important IUGS-sponsored conferences. The first 3 beneficiaries of the Hutchison "Young Scientist" Foundation attended the 28th International Geological Congress (IGC) in Washington, D.C., in 1989.

Initially, earned interest on the funds available to the Hutchison Foundation were insufficient to sustain comparable grants every four years without seriously eroding the principal. For that reason, the IUGS made no grants from the Foundation for the 30th IGC (1996), preferring instead to strengthen the fund by allowing it to earn interest for a longer period of time and by appealing for donations from the international geologic community. Grants from the Foundation again supported deserving young scientists beginning with the 31st IGC (2000), and should continue for future Congresses. The IUGS would like to expand the resources of the Foundation to make it possible also to offer support to deserving young scientists to attend other important IUGS-sponsored scientific meetings. The Hutchison "Young Scientist" Foundation is a worthy cause that honors a fine, caring man and a distinguished, public-spirited scientist and administrator. The foundation also celebrates and promotes those things that gave Hutch the most professional satisfaction: geology, international scientific collaboration, and stimulating young minds.

The IUGS welcomes contributions to the Hutchison "Young Scientist" Foundation. Please send donations to:

Dr. Antonio Brambati

IUGS Treasurer

Dept. of Geological, Environmental and Marine Sci. (DiSGAM),

University of Trieste, 1-34127 Trieste, ITALY

Tel: +39040 558 2046; Fax: +39040 5582048

E-mail: brambati@univ.trieste.it

Checks in US dollars or Visa/Mastercard (please include account number and expiration date) are preferred in order to avoid the high cost of currency conversions. Residents of the U.S.A. are reminded that charitable gifts of this nature are tax deductible. 